\title{
OPEN Alkalinity of diverse water samples can be altered by mercury preservation and borosilicate vial storage
}

\author{
Benjamin Mos ${ }^{1 凶}$, Ceylena Holloway ${ }^{1}$, Brendan P. Kelaher ${ }^{1}$, Isaac R. Santos ${ }^{1,2}$ \& \\ Symon A. Dworjanyn ${ }^{1}$
}

We compared the effects of preservation and storage methods on total alkalinity $\left(A_{T}\right)$ of seawater, estuarine water, freshwater, and groundwater samples stored for 0-6 months. Water samples, untreated or treated with $\mathrm{HgCl}_{2}, 0.45 \mu \mathrm{m}$ filtration, or filtration plus $\mathrm{HgCl}_{2}$, were stored in polypropylene or borosilicate glass vials for 0,1 , or 6 months. Mean $A_{T}$ of samples treated with $\mathrm{HgCl}_{2}$ was reduced by as much as $49.1 \mu \mathrm{mol} \mathrm{kg} \mathrm{kg}^{-1}(1.3 \%)$. Borosilicate glass elevated $A_{T}$, possibly due to dissolving silicates. There was little change in $\mathrm{A}_{\mathrm{T}}$ of control and filtered samples stored in polypropylene, except for untreated groundwater ( $4.1 \%$ reduction at 6 months). $\mathrm{HgCl}_{2}$ concentrations of $0.02-0.05 \%$ reduced the $A_{T}$ of fresh, estuarine, and ground water samples by as much as $35.5 \mu \mathrm{mol} \mathrm{kg} \mathrm{g}^{-1}$ after 1 month, but had little effect on the $A_{T}$ of seawater. Adding glucose as a carbon source for microbial growth resulted in no $A_{T}$ changes in $0.45 \mu \mathrm{m}$-filtered samples. We suggest water samples intended for $A_{T}$ analyses can be filtered to $0.45 \mu \mathrm{m}$, and stored in polypropylene vials at $4^{\circ} \mathrm{C}$ for at least 6 months. Borosilicate glassware and $\mathrm{HgCl}_{2}$ can be avoided to prevent analytical uncertainties and reduce risks related to use of $\mathrm{Hg}^{2+}$.

Total alkalinity $\left(\mathrm{A}_{\mathrm{T}}\right)$ is a measure of the capacity of water to buffer against changes in acidity. Interest in alkalinity measurements has increased in recent years as research into the global carbon cycle and anthropogenic climate change has intensified. For instance, alkalinity measurements are required to understand the impacts of ocean acidification on marine organisms ${ }^{1}$, resolve feedbacks among aquatic and atmospheric carbon pools ${ }^{2}$, quantify critical processes such as coral reef calcification ${ }^{3}$, model biological and non-biological responses to global warming and increased $\mathrm{CO}_{2}$ levels ${ }^{4}$, and assess novel climate adaptation strategies ${ }^{5}$. Fundamental to the application of $A_{T}$ is its accurate measurement ${ }^{6}$.

Accuracy of $A_{T}$ measurements relies on the methods used to preserve and store samples prior to analysis. These methods are well established for seawater samples ${ }^{7,8}$. There is, however, a paucity of studies comparing the effectiveness of preservation and storage methods for non-oceanic water samples, particularly for samples collected from groundwater or brackish ecosystems. Only three studies have examined aspects of preservation or storage methods for freshwater $\mathrm{A}_{\mathrm{T}}$ samples $^{9-11}$. It is important that storage and preservation methods are investigated for non-marine water samples given there is growing interest in quantifying the role of estuarine, freshwater, and groundwater systems in the global carbon cycle ${ }^{12,13}$.

For logistical reasons, water samples are typically collected and stored for hours to months prior to $\mathrm{A}_{\mathrm{T}}$ analysis. It is necessary to inhibit biological activity in samples because biogeochemical processes can alter $\mathrm{A}_{\mathrm{T}}{ }^{14}$. The conventional method to inhibit biological activity in stored water samples is the addition of a saturated $\mathrm{HgCl}_{2}$ solution, which was first developed for water samples stored for analyses of N, P, and $\mathrm{Si}^{15,16}$. Arguably, the use of $\mathrm{HgCl}_{2}$ became established as the primary preservation method for $\mathrm{A}_{\mathrm{T}}$ samples after 2007 when standard operating procedures (SOP) for analyses of seawater carbonate chemistry were described ${ }^{7}$. There is, however, substantial concern about global mercury levels and pollution ${ }^{17}$ including the use of $\mathrm{HgCl}_{2}$ for water preservation ${ }^{18}$, and the applicability of $\mathrm{HgCl}_{2}$ to samples other than seawater. The toxicity and environmental persistence of $\mathrm{Hg}^{2+}$ presents a health risk for researchers and requires substantial costs for safe handling and disposal ${ }^{19,20}$. In addition, failure to account for the diluting effects of added $\mathrm{HgCl}_{2}$ solutions on $\mathrm{A}_{\mathrm{T}}$ is a potential source of error in analyses ${ }^{7}$. The

${ }^{1}$ National Marine Science Centre, Faculty of Science and Engineering, Southern Cross University, Coffs Harbour, NSW, Australia. ${ }^{2}$ Department of Marine Sciences, University of Gothenburg, Gothenburg, Sweden. ${ }^{\square}$ email: benjamin.mos@scu.edu.au 


\begin{tabular}{|l|l|l|l|l|l|l|l|}
\hline Type & Location & Date & $\begin{array}{l}\text { Total alkalinity } \\
\left(\mu \mathbf{m o l ~}^{-1}\right)\end{array}$ & Salinity & Temperature $\left({ }^{\circ} \mathbf{C}\right)$ & $\mathbf{p H}_{\text {NIST }}$ & $\begin{array}{l}\text { Dissolved } \\
\text { oxygen }\left(\mathbf{m g ~ L}^{-1}\right)\end{array}$ \\
\hline Seawater & $30^{\circ} 16^{\prime} 3.25^{\prime \prime}$ S, & 8 July 2016 & $2293.2(0.6)$ & 33.7 & 20.8 & 7.97 & 9.10 \\
\hline & $153^{\circ} 8^{\prime} 15.59^{\prime \prime} \mathrm{E}$ & 24 October 2018 & $2311.0(1.5)$ & 34.4 & 22.4 & 7.97 & 8.48 \\
\hline & & 27 May 2020 & $2291.2(1.6)$ & 32.0 & 21.4 & 8.14 & 8.54 \\
\hline Estuarine water & $30^{\circ} 17^{\prime} 40.55^{\prime \prime}$ S, & 12 July 2016 & $1594.0(0.8)$ & 18.6 & 16.4 & 7.35 & 8.66 \\
\hline & $153^{\circ} 7^{\prime} 3.17^{\prime \prime} \mathrm{E}$ & $\begin{array}{l}\text { 19 December } \\
\text { 2018 }\end{array}$ & $1296.2(3.4)$ & 14.2 & - & 7.65 & 6.46 \\
\hline & & 2 June 2020 & $1798.2(3.3)$ & 22.0 & 15.3 & 7.63 & 5.93 \\
\hline Freshwater & $30^{\circ} 15^{\prime} 5.95^{\prime \prime} \mathrm{S}$, & 13 July 2016 & $327.7(0.4)$ & $<0.1$ & 15.3 & 7.28 & 9.43 \\
\hline & $153^{\circ} 7^{\prime} 53.94^{\prime \prime} \mathrm{E}$ & 24 October 2018 & $565.1(2.7)$ & $<0.1$ & 20.4 & 7.09 & 6.85 \\
\hline & & 28 May 2020 & $605.9(1.6)$ & $<0.1$ & 17.7 & 6.53 & 6.42 \\
\hline Groundwater & $30^{\circ} 17^{\prime} 56.69^{\prime \prime} \mathrm{S}$, & 14 July 2016 & $3749.9(1.5)$ & 20.3 & 15.1 & 6.94 & 5.01 \\
\hline & $153^{\circ} 8^{\prime} 3.81^{\prime \prime} \mathrm{E}$ & $\begin{array}{l}\text { 19 December } \\
\text { 2018 }\end{array}$ & $2722.9(1.2)$ & 23.1 & 25.6 & 6.79 & 3.96 \\
\hline & & 3 June 2020 & $12,382.3(22.1)$ & 12.7 & 17.4 & 7.05 & 2.61 \\
\hline
\end{tabular}

Table 1. Location and water parameters for benchmark controls collected from four water sources near Coffs Harbour, New South Wales, Australia. Values in parentheses are standard deviations, $n=5$. -, not available.

drawbacks of $\mathrm{HgCl}_{2}$ have driven the search for low-cost, safer, and more environmentally benign alternatives ${ }^{18}$. Filtration does not affect the $\mathrm{A}_{\mathrm{T}}$ of alpine freshwater ${ }^{9}$, pond water ${ }^{11}$, or seawater ${ }^{21-23}$. Filtration is as or more effective than $\mathrm{HgCl}_{2}$ in preserving stable isotope compositions $\left(\delta^{13} \mathrm{C}\right)$ in dissolved inorganic carbon ${ }^{24,25}$. However, there has been no systematic comparison of the efficacy of $\mathrm{HgCl}_{2}$ and filtration in preserving $\mathrm{A}_{\mathrm{T}}$.

In addition to biological activity, $\mathrm{A}_{\mathrm{T}}$ can be influenced by the material in which water samples are stored. SOP guidelines for seawater analysis recommend samples are collected and stored in borosilicate glass bottles with ground-glass stoppers ${ }^{7}$. Seawater $\mathrm{A}_{\mathrm{T}}$ concentrations can be elevated by leachates from soda-lime glassware ${ }^{8}$, with the potential to introduce additional errors into calculations of carbonate chemistry parameters via inaccurate $\mathrm{A}_{\mathrm{T}}$ values $^{23}$. Laboratory borosilicate glassware leach acid-neutralising silicates and phosphates at varying rates depending on the $\mathrm{pH}$, temperature, and salinity of the water ${ }^{26-28}$. The capacity of leachates from borosilicate glass storage vessels to alter $\mathrm{A}_{\mathrm{T}}$ remains unclear. The only study to test the effects of borosilicate glass vials on $\mathrm{A}_{T}$ used standards stored in borosilicate glass bottles as benchmarks, and removed outliers that might have been attributable to leachates ${ }^{8}$. Groundwater may be particularly susceptible to overestimation of $\mathrm{A}_{\mathrm{T}}$ due to variable $\mathrm{pH}$ and complex chemical composition altering the rate of borosilicate glass dissolution (e.g. ${ }^{29,30}$ ), but this has not been tested. With growing interest in quantifying the contribution of submarine groundwater discharge to the marine carbon cycle ${ }^{31}$, it is important to refine the techniques for measuring $A_{T}$ in groundwater. Polyethylene and polypropylene have shown promise as inert, inexpensive, and robust alternatives to glass for storing drinking water and seawater samples prior to $\mathrm{A}_{\mathrm{T}}$ analysis ${ }^{8,10}$.

In this study, we tested the efficacy of practical, low-cost, and safer alternatives to the use of $\mathrm{HgCl}_{2}$ and borosilicate glass for $\mathrm{A}_{\mathrm{T}}$ preservation and storage of seawater, groundwater, estuarine water, and freshwater samples (Table 1). We treated water samples using a saturated $\mathrm{HgCl}_{2}$ solution, $0.45 \mu \mathrm{m}$ filtration, or the combination of $\mathrm{HgCl}_{2}$ and filtration. We stored the treated samples and untreated controls for 0,1 , or 6 months in polypropylene or borosilicate glass vials. To assess the effectiveness of the preservation methods and storage vessels, we compared $A_{T}$ values in all treatments to the respective $A_{T}$ of untreated water from the four sources measured at the beginning of the experiment. To understand whether the amount of $\mathrm{HgCl}_{2}$ affects $\mathrm{A}_{\mathrm{T}}$, we compared concentrations of $0,0.002,0.02,0.05,0.2$, and $0.5 \% \mathrm{HgCl}_{2}$ on the $\mathrm{A}_{\mathrm{T}}$ of seawater, groundwater, estuarine water, and freshwater samples stored for 0 and 1 months. Finally, to evaluate whether high dissolved organic carbon (DOC) concentrations that promote biological activity influence the efficacy of different preservation methods, we added glucose to treated $\left(\mathrm{HgCl}_{2}\right.$, filtration) and control water samples, and measured $\mathrm{A}_{\mathrm{T}}, \mathrm{DOC}, \mathrm{pH}$, and dissolved oxygen (DO) after 0 and 1 months.

\section{Materials and methods}

Study sites and sample collection. Water samples from four sources were collected from locations near Coffs Harbour, NSW, Australia; hereafter called seawater, estuarine water, freshwater, and groundwater. Commonly reported parameters for each water source are shown in Table 1 . Water was collected in a 20-L polyethylene drum triple rinsed with the sample water at each location, and transported to the laboratory for processing within $1 \mathrm{~h}$.

Effects of preservation and storage methods on $A_{T}$. An experiment tested the effects of storage vessel material, preservation method, and storage period on $A_{T}$ using a fully crossed design $(2$ materials $\times 4$ preservation methods $\times 3$ storage periods), resulting in 24 treatments for each of the four water sources (collected July 2016, Table 1). There were five replicate samples for each treatment combination $(24$ treatments $\times 5$ replicates per treatment $=$ total 120 independent samples for each water source). The preservation methods were (1) the addition of $100 \mu \mathrm{L}$ saturated $\mathrm{HgCl}_{2}$ solution $\left(25^{\circ} \mathrm{C}\right)$, equivalent to $0.2 \%$ of the volume of water samples, (2) filtration 
using a disposable filter $(0.45 \mu \mathrm{m}$, Sartorius Minisart NML), or (3) filtration followed by the addition of $100 \mu \mathrm{L}$ saturated $\mathrm{HgCl}_{2}$ solution $\left(25^{\circ} \mathrm{C}\right)$. The control treatment was not filtered and did not have $\mathrm{HgCl}_{2}$ added. Treated and control samples were stored in either gas tight glass vials $(\sim 44 \mathrm{~mL}$, Thermo Fisher Scientific B7950, Type 1, Class A, 33 expansion borosilicate glass) or polypropylene vials ( $38 \mathrm{~mL}$, Techno Plas P8027UU) for 0, 1, or 6 months.

Vials were prepared by cleaning in a $1 \mathrm{M} \mathrm{HCl}$ bath for $\sim 24 \mathrm{~h}$, followed by rinsing for $\sim 24 \mathrm{~h}$ in Milli-Q water (18.2 $\mathrm{M} \Omega \mathrm{cm}^{-1}$ resistivity). Glass vials were then wrapped in aluminium foil and placed in a $450{ }^{\circ} \mathrm{C}$ muffle furnace for $4 \mathrm{~h}$ to remove organic carbon. Polypropylene vials were dried at room temperature. All vials were tripled rinsed with either the filtered or unfiltered water type according to the assigned treatment, before filling. The vials were filled until a convex meniscus formed and then capped. Capped vials containing samples assigned time 0 were analysed within $3 \mathrm{~h}$ of capping. The remaining capped vials were stored in a refrigerator $\left(4^{\circ} \mathrm{C}\right)$ for either 1 or 6 months before analysis to look for changes related to the different processing approaches. Aliquots of the seawater, estuarine water, freshwater, and groundwater $(10 \mathrm{~mL}, \mathrm{n}=5)$ taken directly from the 20 - $\mathrm{L}$ drums within 90 min of collection, were analysed (Table 1) and used as benchmark controls to assess changes in $\mathrm{A}_{\mathrm{T}}$.

Effects of $\mathrm{HgCl}_{2}$ concentration on $\mathrm{A}_{\mathrm{T}}$. An experiment tested the effects of the final concentration of saturated $\mathrm{HgCl}_{2}$ in water samples on $\mathrm{A}_{\mathrm{T}}$ using a fully crossed design $\left(6 \mathrm{HgCl}_{2}\right.$ concentrations $\times 2$ storage periods), resulting in 12 treatments for each of the four water sources (collected October or December 2018, Table 1). There were five replicate samples for each treatment combination ( 12 treatments $\times 5$ replicates per treatment $=$ total 60 independent samples per water source). All water samples were filtered $(0.45 \mu \mathrm{m}$, Sartorius Minisart NML) and placed in polypropylene vials ( $38 \mathrm{~mL}$, Techno Plas P8027UU) as previously described. Aliquots $(1,10,25,100$, or $200 \mu \mathrm{L})$ of saturated $\mathrm{HgCl}_{2}$ solution $\left(25^{\circ} \mathrm{C}\right)$ were added, equivalent to $0.002,0.02,0.05,0.2$, or $0.5 \%$ of the volume of water samples, respectively. A control ( $0 \%)$ treatment did not have mercury added. Initial ( 0 month) water samples without mercury were used as benchmark controls (water parameters including $A_{T}$ are shown in Table 1). All samples designated time 0 were analysed within $3 \mathrm{~h}$. The remaining vials were stored in a refrigerator $\left(4^{\circ} \mathrm{C}\right)$ for 1 month before analysis.

Effect of glucose enrichment on the efficacy of preservation methods. An experiment tested the effects of preservation method, water source, and storage period on $\mathrm{A}_{\mathrm{T}}$ in the presence of high dissolved organic carbon (DOC) levels achieved by the addition of dissolved glucose. High DOC levels promote microbial activity, particularly respiration, which has the potential to alter the carbonate chemistry of stored water samples ${ }^{22,32}$. A fully crossed design was used ( 3 preservation methods $\times 2$ storage periods $\times 2$ DOC treatments), resulting in 12 treatments for each of the four water sources (collected May or June 2020, Table 1). The preservation methods included the addition of $100 \mu \mathrm{L}$ saturated $\mathrm{HgCl}_{2}$ solution $\left(25^{\circ} \mathrm{C}\right)$, equivalent to $0.2 \%$ of the volume of water sample, or filtration using a disposable filter $(0.45 \mu \mathrm{m}$, Sartorius Minisart NML). A control treatment was not filtered and did not have $\mathrm{HgCl}_{2}$ added. A high DOC treatment was created by adding aliquots of a concentrated glucose solution (10,000 ppm, Sigma-Aldrich G8270) to water samples (seawater $48.2 \mu \mathrm{L}$; estuarine water $88.8 \mu \mathrm{L}$; freshwater $104.3 \mu \mathrm{L}$; groundwater $457.9 \mu \mathrm{L})$. This treatment increased DOC by an order of magnitude $(\sim 10-15$ times $)$ compared to levels measured in untreated benchmark controls (Supplementary Information Table S1). These DOC concentrations are at the extreme upper limit typically measured in diverse water samples ${ }^{33}$. An ambient DOC treatment did not have glucose solution added.

There were eight replicates for each treatment combination (12 treatments $\times 8$ replicates per treatment $=96$ independent samples per water source). Five replicates were used to monitor $A_{T}$ and DOC. To avoid crosscontamination, the remaining three replicates were used to measure $\mathrm{pH}$ and dissolved oxygen (DO) at the designated sampling time using a Hach HQ40d multicontroller fitted with a LDO101 DO probe and a PHC301 $\mathrm{pH}$ probe calibrated with Metrohm buffers (6.2307.230). Measurements of $\mathrm{pH}$ were recorded on the NIST scale $\left(\mathrm{pH}_{\mathrm{NIST}}\right)$. Treated and control samples were stored in polypropylene vials ( $38 \mathrm{~mL}$, Techno Plas P8027UU) for 0 or 1 month, as previously described. Initial $(0$ month $)$ water samples that were not filtered and did not have mercury or glucose added were used as benchmark controls for $\mathrm{A}_{T}$ (water parameters including $\mathrm{A}_{\mathrm{T}}$ are shown in Table 1). Benchmark controls for DOC, $\mathrm{pH}$, and DO were defined for treated and control water samples (Supplementary information Table S1). All samples designated time 0 were analysed within $3 \mathrm{~h}$. The remaining vials were stored in a refrigerator $\left(4^{\circ} \mathrm{C}\right)$ for 1 month before analysis.

Sample analyses. Each replicate vial was destructively sampled at its assigned sampling time; for instance, replicates assigned to a 1 month storage treatment were not measured again at 6 months. To measure total alkalinity $\left(\mathrm{A}_{\mathrm{T}}\right)$, a $10 \mathrm{~mL}$ aliquot from each vial was analysed by potentiometric titration using a Metrohm 888 Titrando $^{7}$, calibrated using certified reference materials (Batch 116 for 2016/17 analyses; Batch 166 for 2018/19 analyses; Batch 170 for 2020 analyses ${ }^{34}$ ), and titration protocols tailored to each water source developed during previous research $\left(\right.$ e.g. $\left.{ }^{2,5}\right)$. The protocols ensured the titrations generated sufficient data points by, for example, tailoring the rate at which acid was added to a sample. $\mathrm{NaCl}$ was added to the $\mathrm{HCl}$ titrant to match the respective salinity of the four water sources (Table 1 ) (SOP $3^{7}$ ). Samples were warmed in a $25^{\circ} \mathrm{C}$ water bath prior to analysis, and analyses were carried out in a temperature-controlled room $\left(25^{\circ} \mathrm{C}\right)$. At the designated sampling time $(0,1$, or 6 months), all samples from a single water source were analysed in a haphazard order within $3 \mathrm{~h}$ after reaching ambient temperature $\left(25^{\circ} \mathrm{C}\right)$. To monitor precision and check for drift, certified reference materials (Batch 116,166 , or 170 respectively) were analysed prior to the commencement of sample analyses and once every 20th sample (every 1-2 h). Across all analyses of reference material, precision was better than $2.3 \mu \mathrm{mol} \mathrm{kg}^{-1}(\mathrm{n}=3-5)$. $\mathrm{A}_{\mathrm{T}}$ values were calculated using the Gran approach, and, where applicable, corrected for dilution by the $\mathrm{HgCl}_{2}$ solution and/or glucose solution ${ }^{7}$. The Gran approach is endorsed by Dickson et al.s Guide to Best Practice ${ }^{7}$ and 
the US Geological Survey TWRI Book ${ }^{35}$, is commonly used internationally (e.g. ${ }^{36-38}$ ), and is the only method suitable for all of the four water sources examined in this study ${ }^{35}$. The Gran approach and curve fitting generate similar alkalinity values, often within $0.1 \%$ or $1 \mu \mathrm{mol} \mathrm{L}-1\left(\right.$ e.g. $\left.{ }^{39,40}\right)$. Any differences between the two calculations are likely less than our error, and would therefore have no material impact on our results or conclusions. Data were used to calculate $\Delta \mathrm{A}_{T}$ for each replicate, the difference between the $\mathrm{A}_{T}$ of the replicate and the mean $\mathrm{A}_{T}$ of the respective benchmark control (see Table 1 for $\mathrm{A}_{\mathrm{T}}$ values of benchmark controls). Standard deviations of $\Delta \mathrm{A}_{\mathrm{T}}$ for each treatment were calculated according to SOP $23^{7}$.

To measure dissolved organic carbon (DOC), a $3 \mathrm{~mL}$ aliquot from each vial was analysed by the wet oxidation method using a OI analytical Aurora 1030 TOC analyser (OI Analytical, USA), with an accuracy of $4 \%$ and precision of $2 \%$. Where applicable, DOC values were corrected for dilution by the $\mathrm{HgCl}_{2}$ solution ${ }^{7}$. Data were used to calculate $\triangle D O C$ for each replicate, i.e. the difference between the DOC of the replicate and the mean DOC of the respective benchmark control. Standard deviations of $\triangle \mathrm{DOC}$ for each treatment were calculated according to SOP $23^{7}$.

Statistical analysis. Dunnett's T3 tests were used to determine if $\mathrm{A}_{\mathrm{T}}, \mathrm{DOC}, \mathrm{pH}$, and $\mathrm{DO}$ values in temporal treatments, added $\mathrm{HgCl}_{2}$ volume treatments, or added glucose treatments were significantly different from values measured in their respective benchmark control, using IBM SPSS Statistics (v25.0).

\section{Results}

Effects of preservation and storage methods on $A_{T}$. The storage vessel and preservation method had significant effects on $\mathrm{A}_{\mathrm{T}}$ (Fig. 1). Mean $\mathrm{A}_{\mathrm{T}}$ of freshwater and seawater samples stored in glass vials generally increased over time by $1.6-13.6 \mu \mathrm{mol} \mathrm{kg}{ }^{-1}$ compared to their respective benchmark control (Fig. 1). There were no significant differences in the $\mathrm{A}_{\mathrm{T}}$ of estuarine water samples stored in glass vials compared to the benchmark control, although mean $\Delta \mathrm{A}_{\mathrm{T}}$ was generally above (after 0 or 1 month) or below (after 6 months) two standard deviations of the benchmark control (i.e. within $\pm 0.8-3.0 \mu \mathrm{mol} \mathrm{kg}{ }^{-1}$ respectively) (Fig. 1, Table 1). In contrast, the $A_{T}$ of seawater, estuarine water, and freshwater samples stored in polypropylene vials for 0,1 , or 6 months were not different than the $A_{T}$ of their respective benchmark controls, except for mercury and filter + mercury treatments where mean $\mathrm{A}_{\mathrm{T}}$ was reduced by $0.9-12.7 \mu \mathrm{mol} \mathrm{kg}{ }^{-1}$ compared to the benchmark controls (Fig. 1). For groundwater, the mean $A_{T}$ of samples held in glass and polypropylene vials generally declined by 7.6-153.0 $\mu \mathrm{mol} \mathrm{kg}{ }^{-1}$, except for the filter only treatment where $A_{T}$ was generally equivalent to the benchmark control (Fig. 1).

There were no significant differences in $\mathrm{A}_{\mathrm{T}}$ between control treatments (i.e. no filtration or $\mathrm{HgCl}_{2}$ ) at 0,1 , or 6 months and their respective benchmark control for seawater, estuarine water, and freshwater samples stored in polypropylene (Fig. 1). Conversely, seawater, estuarine water, and freshwater samples held in glass vials experienced increases in $\mathrm{A}_{\mathrm{T}}$ over time in control treatments by up to $13.6 \mu \mathrm{mol} \mathrm{kg}{ }^{-1}$ after 6 months. For groundwater samples, $A_{T}$ in the control treatments declined regardless of the type of material they were stored in, falling by 3.7-4.1\% after 6 months (Fig. 1). For all water sources, mean $\Delta \mathrm{A}_{\mathrm{T}}$ of filtered samples were always comparable to the mean $\mathrm{A}_{\mathrm{T}}$ of their respective benchmark controls (i.e. within $\pm 0.8-3.0 \mu \mathrm{mol} \mathrm{kg}{ }^{-1}$ respectively). In contrast, mean $\mathrm{A}_{\mathrm{T}}$ for all water sources treated with $\mathrm{HgCl}_{2}$ or the combination of $\mathrm{HgCl}_{2}$ and filtration were generally lower than in benchmark controls by $<49.1 \mu \mathrm{mol} \mathrm{kg}{ }^{-1}$, except for freshwater and seawater samples stored in glass vials where mean $\mathrm{A}_{\mathrm{T}}$ increased over time by $<11.3 \mu \mathrm{mol} \mathrm{kg}{ }^{-1}$ after 6 months (Fig. 1).

Effects of $\mathrm{HgCl}_{2}$ concentration on $\mathrm{A}_{\mathrm{T}}$. For estuarine water, freshwater, and groundwater samples, the effects of mercury preservation on $\mathrm{A}_{\mathrm{T}}$ differed depending on how much saturated $\mathrm{HgCl}_{2}$ was added (Fig. 2). Mean $\mathrm{A}_{\mathrm{T}}$ of estuarine water was reduced by $9.0-13.2 \mu \mathrm{mol} \mathrm{kg}-1$ by the addition of $0.05 \%$ or $\operatorname{more} \mathrm{HgCl}_{2}$ at time 0 . After 1 month, estuarine water $A_{T}$ fell by $11.2-12.2 \mu$ mol kg${ }^{-1}$ in 0.2 and $0.5 \% \mathrm{HgCl}_{2}$ treatments. Mean $\mathrm{A}_{\mathrm{T}}$ of freshwater was reduced by $8.1 \mu \mathrm{mol} \mathrm{kg}{ }^{-1}$ by the addition of $0.5 \% \mathrm{HgCl}_{2}$ at time 0 , and after $1 \mathrm{month}$, fell by 13.0-26.8 $\mu \mathrm{mol} \mathrm{kg}-1$ in all treatments that had $\mathrm{HgCl}_{2}$ added compared to the benchmark control (Table 1). Mean $\mathrm{A}_{\mathrm{T}}$ of groundwater was always reduced by $9.6-44.1 \mu \mathrm{mol} \mathrm{kg}-1$ by the addition of $0.02 \%$ or more $\mathrm{HgCl}_{2}$, but there was no difference in the $\mathrm{A}_{\mathrm{T}}$ of samples with $0.002 \% \mathrm{HgCl}_{2}$ and benchmark controls. In contrast to the other water sources, mean $\mathrm{A}_{\mathrm{T}}$ of seawater samples treated with $\mathrm{HgCl}_{2}$ were generally not different from the $\mathrm{A}_{T}$ of the benchmark control (initial $0 \%$ treatment, Table 1), although mean $\Delta \mathrm{A}_{\mathrm{T}}$ of $0.05,0.2$, and $0.5 \%$ treatments were generally below two standard deviations of the benchmark control (Fig. 2, Table 1). For all water sources, $A_{T}$ in control treatments without mercury after 1 month were comparable to benchmark controls, except for groundwater where $\mathrm{A}_{\mathrm{T}}$ fell by $17.5 \mu \mathrm{mol} \mathrm{\textrm {kg } ^ { - 1 }}$.

Effect of glucose enrichment on the efficacy of preservation methods. The addition of glucose to increase dissolved organic carbon (DOC) generally had little effect on all types of samples (Fig. 3, Table 1). For seawater, filtered samples had the same $A_{T}$ as the benchmark control after 0 and 1 month regardless of whether glucose was added (Fig. 3, Table 1). The control treatment also had similar $\mathrm{A}_{\mathrm{T}}$ to the benchmark control, except after 1 month in the control/glucose added treatment where $A_{T}$ fell by $12.2 \mu \mathrm{mol} \mathrm{kg}^{-1}$. Seawater treated with mercury had higher $\mathrm{A}_{\mathrm{T}}$ than the benchmark control $\left(\Delta \mathrm{A}_{\mathrm{T}} 2.8-7.0 \mu \mathrm{mol} \mathrm{kg}{ }^{-1}\right)$, although this increase was only statistically significant for samples without added glucose (Fig. 3 ).

For freshwater and groundwater after 0 month, and estuarine water after 0 and 1 month, most treatments had similar $\mathrm{A}_{\mathrm{T}}$ to the benchmark control (Fig. 3, Table 1). After 1 month, $\mathrm{A}_{\mathrm{T}}$ in the freshwater control treatment without glucose increased by $7.9 \mu \mathrm{mol} \mathrm{kg}{ }^{-1}$ (Fig. 3, Table 1). Freshwater with $\mathrm{HgCl}_{2}$ added had lower $\mathrm{A}_{\mathrm{T}}$ than the benchmark control at time $0\left(\Delta \mathrm{A}_{\mathrm{T}} 4.1-4.8 \mu \mathrm{mol} \mathrm{kg}{ }^{-1}\right)$, although this decrease was only statistically significant for samples without added glucose (Fig. 3). After 1 month, freshwater with added $\mathrm{HgCl}_{2}$ had either higher 

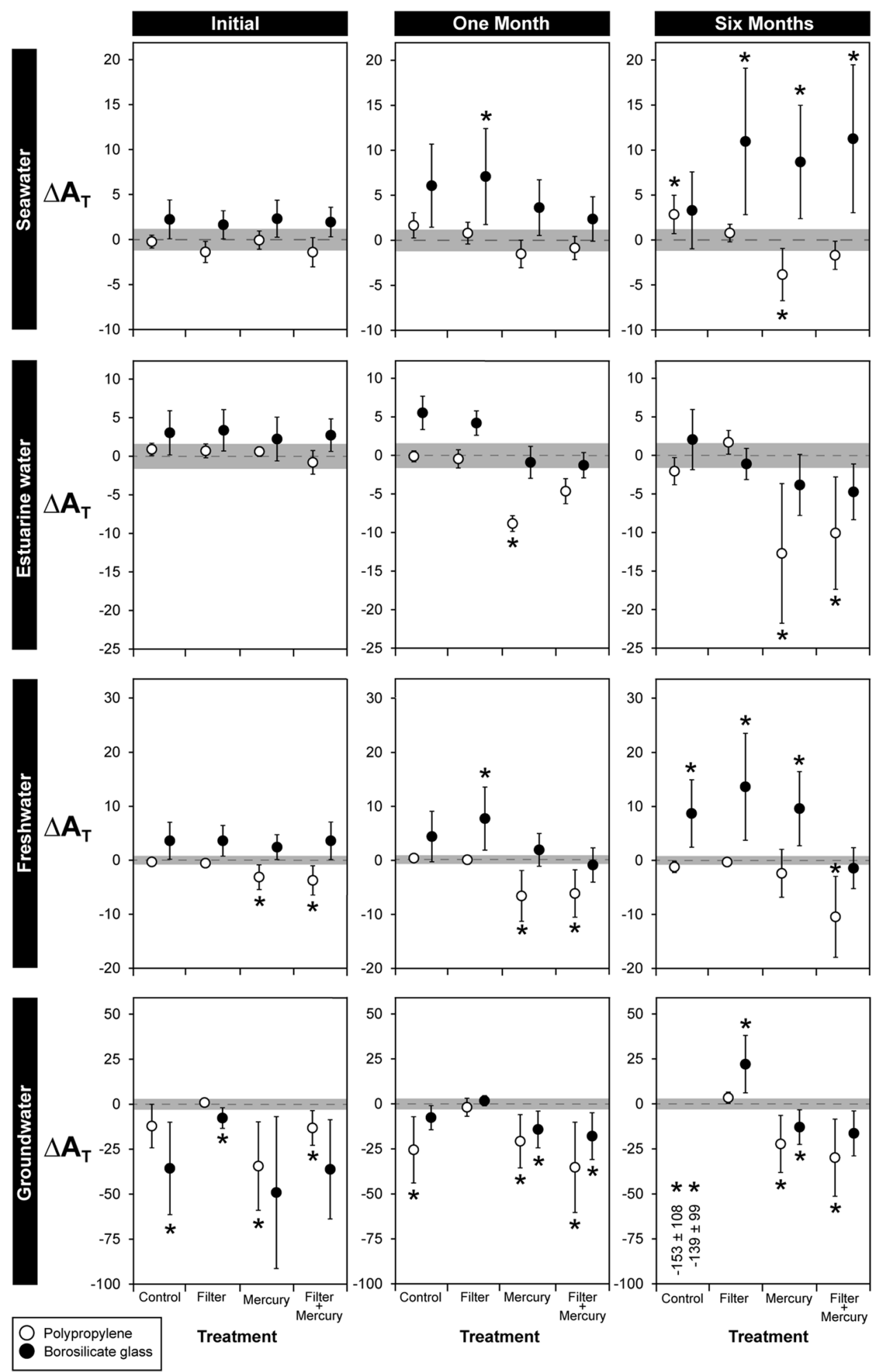

Figure 1. The effects of storage vessel material and preservation method on difference in total alkalinity $\left(\Delta \mathrm{A}_{\mathrm{T}}\right)$ of seawater, estuarine water, freshwater, and groundwater samples stored for 0,1 , and 6 months. All results represent the difference between observations and the mean $A_{T}$ of untreated samples measured at the beginning of the experiment $\left(A_{T}\right.$ values of benchmark controls shown in Table 1). Water samples were treated using one of four methods (no treatment; $0.45 \mu \mathrm{m}$ filter; $100 \mu \mathrm{L}$ saturated $\mathrm{HgCl}_{2}$ solution $\left(25^{\circ} \mathrm{C}\right.$ ); filter $\left.+\mathrm{HgCl}_{2}\right)$. Samples were then stored in either polypropylene (white) or borosilicate glass (black) vials at $4{ }^{\circ} \mathrm{C}$ for 0,1 , or 6 months. Shaded areas on graphs represent \pm 2 standard deviations of the respective benchmark control (Table 1). Asterisks indicate there was a significant difference in $A_{T}$ of samples in a treatment compared to the $A_{T}$ of the benchmark control according to Dunnett's tests, and should not be used to evaluate statistical difference or similarity among treatments. Data are means \pm 1 standard deviation. $\mathrm{n}=5$ except for the seawater 6 months/ glass/Control treatment where $\mathrm{n}=4$. As mean $\Delta \mathrm{A}_{\mathrm{T}}$ for the groundwater $6 \mathrm{month} /$ Control treatments were greater than $-100 \mu \mathrm{mol} \mathrm{kg}{ }^{-1}$, values are given on the figure (means \pm 1 S.D.). 

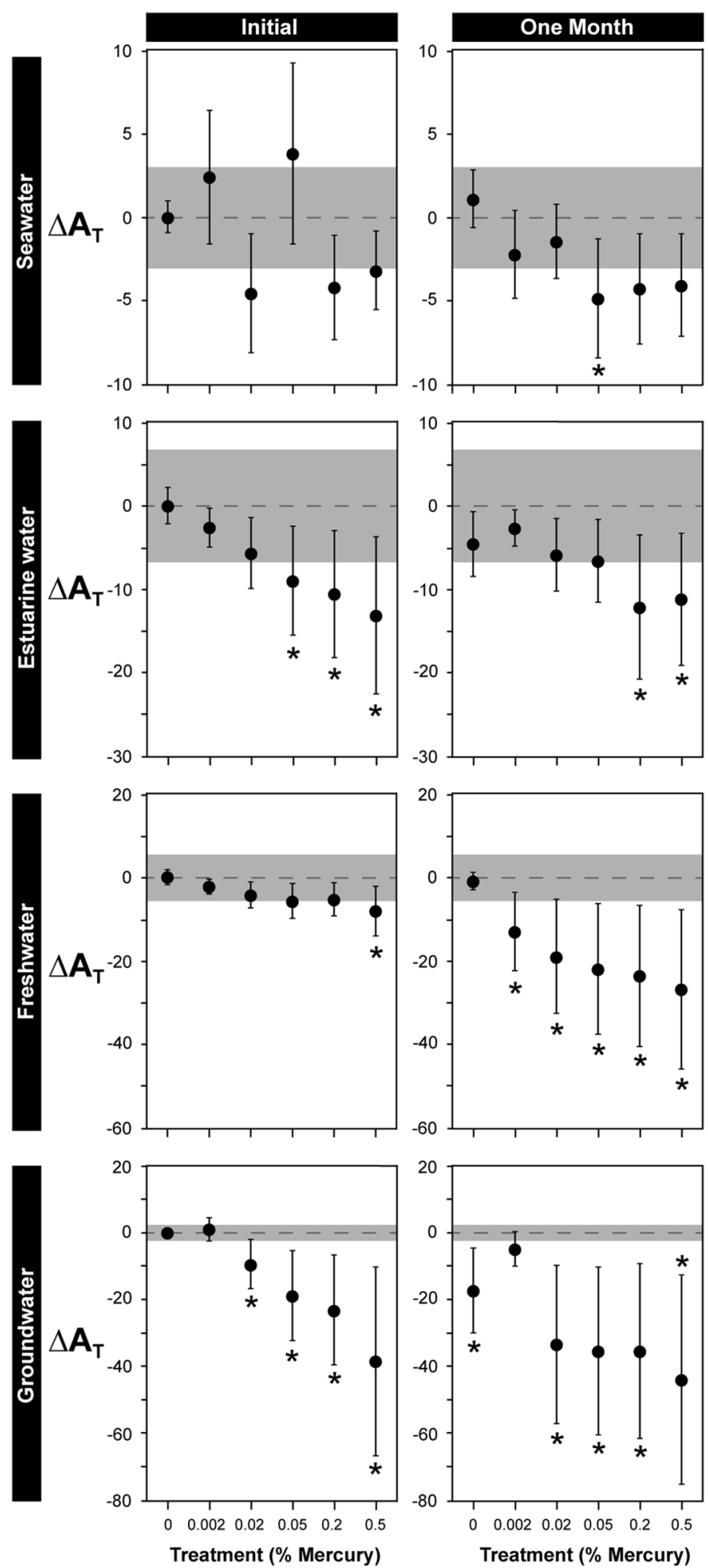

Figure 2. The effects of mercury concentration on total alkalinity $\left(\Delta \mathrm{A}_{\mathrm{T}}\right)$ of seawater, estuarine water, freshwater, and groundwater samples stored for 0 or 1 months. Results represent the difference between observations and the mean $A_{T}$ of untreated samples measured at the beginning of the experiment $\left(A_{T}\right.$ of benchmark controls are shown in Table 1). Shaded areas on graphs represent \pm 2 standard deviations of the respective benchmark control (Table 1). Asterisks indicate there was a significant difference in $A_{T}$ of samples in a treatment compared to the $A_{T}$ of the benchmark control according to Dunnett's tests, and should not be used to evaluate statistical difference or similarity among treatments. Data are means \pm 1 standard deviation. $\mathrm{n}=5$ except for the freshwater $0.05 \%$ mercury/1 month treatment where $\mathrm{n}=4$. 


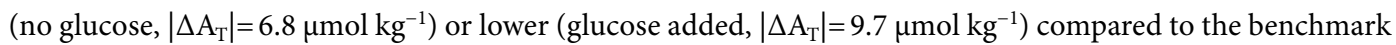
control (Fig. 3, Table 1).

$\mathrm{A}_{\mathrm{T}}$ in groundwater samples that had $\mathrm{HgCl}_{2}$ added fell by $210.5-313.5 \mu \mathrm{mol} \mathrm{kg} \mathrm{kg}^{-1}$ at time 0 compared to the benchmark control (Fig. 3, Table 1). After 1 month, $A_{\mathrm{T}}$ in all groundwater treatments had decreased by $11-20 \%$ compared to the benchmark control (Fig. 3, Table 1). Grey-white precipitates were observed in the 1 month control and filtered samples, and black precipitates observed in the 1 month $\mathrm{HgCl}_{2}$ treated samples.

There were no clear differences in the effects of preservation treatments on DOC, $\mathrm{pH}$, and dissolved oxygen (DO) regardless of whether samples had glucose solution added (see Supplementary Information). After 1 month, DOC was either the same as or $17-50 \%$ lower than the corresponding benchmark control, with decreases in DOC most apparent for groundwater (Supplementary Information Fig. S1, Table S1). However, $\Delta$ DOC were generally consistent among preservation treatments for all water sources.

For all water sources, $\mathrm{pH}$ and $\mathrm{DO}$ in all treatments at time 0 were generally equivalent to levels in the corresponding benchmark controls (Supplementary Information Fig. S1, Table S1). However, estuarine water samples with $\mathrm{HgCl}_{2}$ added had significantly lower $\mathrm{pH}$ than the corresponding benchmark control (Supplementary Fig. S1, Table S1). After 1 month, $\mathrm{pH}$ generally decreased in all treatments by mean $0.1-1.2 \mathrm{pH}$ units regardless of whether samples had glucose added. For all water types, DO generally increased after 1 month by a similar amount in all treatments $\left(0.5-4.3 \mathrm{mg} \mathrm{L}^{-1}\right)$, except for groundwater samples with added glucose where DO remained stable across all treatments.

\section{Discussion}

We tested the effects of common storage and preservation methods on the $\mathrm{A}_{\mathrm{T}}$ of diverse water samples, building on earlier work that focused primarily on seawater samples ${ }^{7,8}$. Estuarine water, freshwater, seawater, and groundwater samples were significantly altered when stored in borosilicate glass vials or treated with $\mathrm{HgCl}_{2}$. In contrast, samples filtered to $0.45 \mu \mathrm{m}$ and/or stored in polypropylene vials for up to 6 months were generally comparable to their benchmark controls. The combination of $0.45 \mu \mathrm{m}$ filtration and storage in polypropylene vials was the only treatment that consistently prevented changes in $\mathrm{A}_{\mathrm{T}}$ across most water sources (i.e. within two standard deviations of the benchmark control, $\pm 0.8-3.0 \mu \mathrm{mol} \mathrm{kg}{ }^{-1}$, respectively), and was equivalent or more effective than $\mathrm{HgCl}_{2}$ even when samples were enriched in glucose to promote microbial activity. Based on these results, we contend that filtration and polypropylene are viable alternatives to the use of $\mathrm{HgCl}_{2}$ and borosilicate glass for preservation and storage of $A_{T}$ water samples collected from a range of aquatic environments.

The use of poisonous mercury may not be necessary when storing water samples for $\mathrm{A}_{\mathrm{T}}$ analyses. The addition of saturated $\mathrm{HgCl}_{2}$ was often associated with substantial reductions in the $\mathrm{A}_{\mathrm{T}}$ of freshwater, estuarine water, or groundwater samples stored for 1 or 6 months. It is unlikely that mercury-resistant bacteria reduced $A_{T}$ in these treatments $\left(\mathrm{see}^{34}\right)$ because $\mathrm{A}_{\mathrm{T}}$ was reduced to the same extent in filter + mercury treatments and mercury only treatments. Instead, $\mathrm{Hg}^{2+}$ may have reduced $\mathrm{A}_{\mathrm{T}}$ by forming complexes with dissolved organic matter (DOM), a component of $\mathrm{A}_{\mathrm{T}}{ }^{41-43}$. DOM interacts strongly with mercury ${ }^{44}$. For example, $45-100 \%$ of $\mathrm{Hg}^{2+}$ in coastal seawater can be organically complexed with DOM, with the remainder complexed with $\mathrm{Cl}^{-}$or $\mathrm{OH}^{-}$ions ${ }^{45}$. Mercury is more likely to be found in complexes with $\mathrm{Cl}^{-}$than $\mathrm{OH}^{-}$when $\mathrm{Cl}^{-}$levels exceed $\sim 350 \mathrm{mg} \mathrm{L}^{-1}$, although this is dependent on $\mathrm{pH}^{19,46}$. Variability in $\mathrm{DOM}$ or $\mathrm{Cl}^{-}$concentrations might therefore explain why the reducing effects of $\mathrm{HgCl}_{2}$ on $\mathrm{A}_{\mathrm{T}}$ in our study were smallest in seawater.

The degree to which $\mathrm{HgCl}_{2}$ reduced $\mathrm{A}_{\mathrm{T}}$ often depended on the concentration used, but this was not consistent among all water sources. The addition of $\geq 0.2 \% \mathrm{HgCl}_{2}$ to estuarine water and $\geq 0.02 \% \mathrm{HgCl}_{2}$ to freshwater and groundwater significantly reduced mean $\mathrm{A}_{\mathrm{T}}$ by anywhere from $0.9 \%$ to $4.7 \%$ after 1 month. In contrast, $\mathrm{A}_{\mathrm{T}}$ of seawater was not consistently altered by any of the $\mathrm{HgCl}_{2}$ concentrations tested. We are not aware of any studies that have examined the effects of $\mathrm{HgCl}_{2}$ concentration on $\mathrm{A}_{\mathrm{T}}$, but the concentrations that we tested $(0.02-0.05 \%)$ are often recommended to preserve samples before $A_{T}$ analysis ${ }^{7}$. Our results demonstrate that standard levels of $\mathrm{HgCl}_{2}$ used to preserve water samples can reduce the accuracy of $\mathrm{A}_{\mathrm{T}}$ measurements, particularly for freshwater and groundwater samples, further highlighting the need to identify alternative methods for storing non-oceanic water samples.

Instead of $\mathrm{HgCl}_{2}$ preservation, the accuracy of $\mathrm{A}_{\mathrm{T}}$ analyses can be improved by using filtration to inhibit biological activity in water samples. Filtration has added benefits in that it increases safety for researchers and reduces the costs of managing $\mathrm{HgCl}_{2}$ poisoned samples. There was no effect of $0.45 \mu \mathrm{m}$ filtration on $\mathrm{A}_{\mathrm{T}}$ of water samples from across a salinity spectrum. Other studies have also found no effects of filtration on the $A_{T}$ of alpine freshwater, pond water, and seawater ${ }^{6,9,11,21,22}$. Importantly there were no changes in the $A_{T}$ of filtered samples stored in polypropylene vials for at least 6 months, with the exception of groundwater in two of three experiments, demonstrating the enduring effectiveness of filtration. Although $\mathrm{A}_{\mathrm{T}}$ was often unchanged for seawater, estuarine water, and freshwater samples that were not treated with $\mathrm{HgCl}_{2}$ or filtered, these water samples should be filtered before storage to prevent changes in $\mathrm{A}_{\mathrm{T}}$ due to particulates or microbes ${ }^{20,22}$. For some types of groundwater, filtration may not be sufficient to prevent changes in $\mathrm{A}_{\mathrm{T}}$ over time, although our results indicate changes in $\mathrm{A}_{\mathrm{T}}$ may be small $(<0.7 \%)$ when $\mathrm{A}_{\mathrm{T}}$ concentrations are $<4000 \mu \mathrm{mol} \mathrm{kg}{ }^{-1}$. We observed precipitates and substantial declines in alkalinity when groundwater samples with very high alkalinity $\left(>12,000 \mu \mathrm{mol} \mathrm{kg}^{-1}\right)$ were stored for 1 month prior to analysis. We hypothesise chemical or biological activity were responsible for changes in the $\mathrm{A}_{\mathrm{T}}$ of filtered or unfiltered groundwater, despite refrigeration. Low temperatures slow, but do not stop, chemical and biological activity (e.g. ${ }^{26}$ ), perhaps also explaining why changes in $\mathrm{A}_{\mathrm{T}}$ in the groundwater control treatments became more apparent over time (e.g. after 6 months, Fig. 1). For groundwater samples, researchers may need to balance the requirements for accuracy and precision of $\mathrm{A}_{\mathrm{T}}$ measurements against the risks and costs associated with using combined filtration and $\mathrm{HgCl}_{2}$ preservation. If highly accurate measurements are required, our results suggest $0.002 \% \mathrm{HgCl}_{2}$ can preserve $0.45 \mu \mathrm{m}$-filtered groundwater for at least 1 month without substantially 


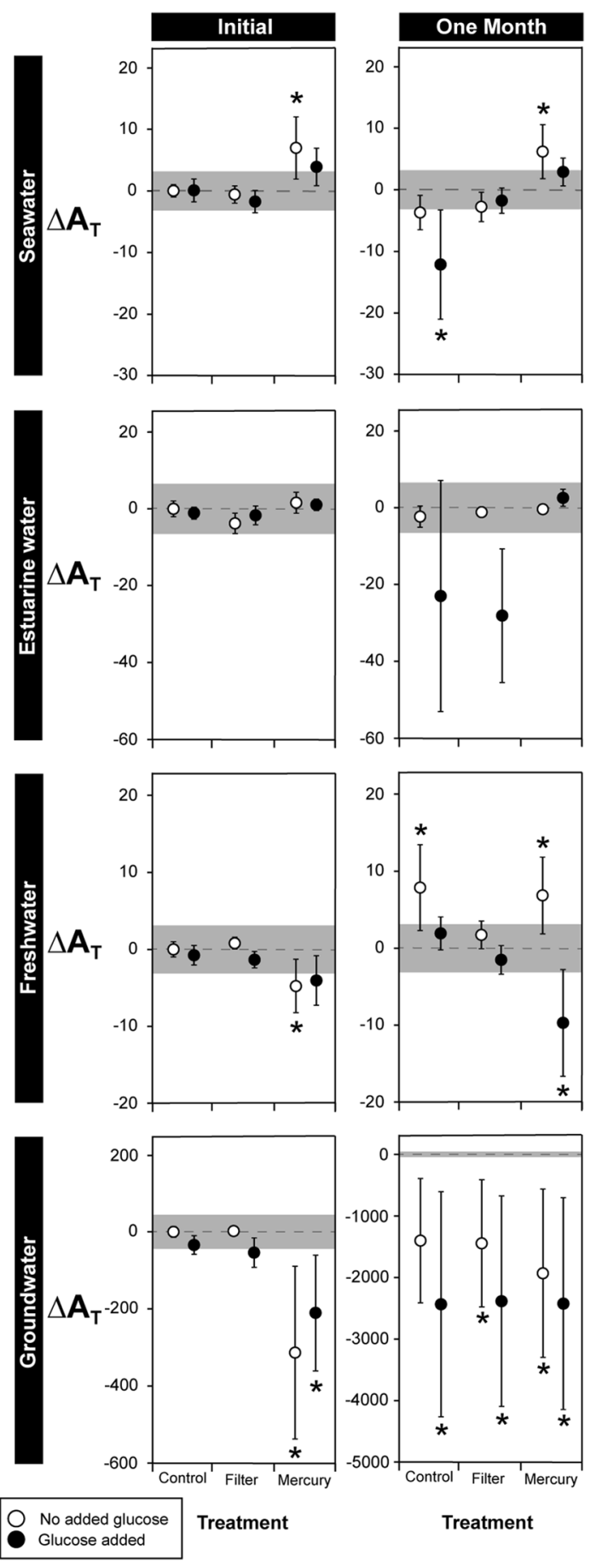

Figure 3. The effects of glucose addition and preservation method on difference in total alkalinity $\left(\Delta \mathrm{A}_{\mathrm{T}}\right)$ of seawater, estuarine water, freshwater, and groundwater samples stored for 0 and 1 month. All results represent the difference between observations and the mean $\mathrm{A}_{\mathrm{T}}$ of untreated samples measured at the beginning of the experiment $\left(\mathrm{A}_{\mathrm{T}}\right.$ values of benchmark controls are shown in Table 1). Water samples were treated using one of three methods (no treatment; $0.45 \mu \mathrm{m}$ filter; $100 \mu \mathrm{L}$ saturated $\mathrm{HgCl}_{2}$ solution $\left(25^{\circ} \mathrm{C}\right.$ )), and had a concentrated glucose solution added (black) or no glucose added (white). Addition of the glucose solution increased dissolved organic carbon (DOC) by 10-15 times compared to ambient levels (Supplementary Information Table S1). Samples were stored in polypropylene vials at $4{ }^{\circ} \mathrm{C}$ for 0 or 1 month. Shaded areas on graphs represent \pm 2 standard deviations of the respective benchmark control (Table 1). Asterisks indicate there was a significant difference in $A_{T}$ of samples in a treatment compared to the $A_{T}$ of the benchmark control according to Dunnett's tests, and should not be used to evaluate statistical difference or similarity among treatments. Data are means \pm 1 standard deviation. $\mathrm{n}=5$. Note: scale of $\mathrm{Y}$ axes differs for groundwater initial and 1 month. 
altering $\mathrm{A}_{\mathrm{T}}$, with the exception that waters with extremely high alkalinity should be analysed as soon as practical to avoid physical or chemical changes. Higher concentrations of mercury do not seem to improve preservation.

Polypropylene vials had no measurable effects on the $A_{T}$ of water samples stored for up to 6 months, adding to growing evidence that plastic vessels are suitable alternatives to glassware storage for $A_{T}$ analyses ${ }^{8,10}$. Conversely, some water samples stored in borosilicate glass vials had elevated $\mathrm{A}_{\mathrm{T}}$, especially in low $\mathrm{pH}$ conditions (i.e. $\mathrm{pH}$ of groundwater $<$ river $<$ estuary < ocean; Table 1 ). This is possibly due to the $\mathrm{pH}$-dependent dissolution of acid neutralising materials from the glass (e.g. borate, silicate, or hydroxyl ions ${ }^{28,47}$ ). The glass vials we used are made to the same specifications as the borosilicate glass bottles recommended by Dickson et al. ${ }^{7,34,48}$, but the glass surface area to water volume ratios are different (our glass vials $=2.0 \mathrm{~cm}^{2} / \mathrm{mL}$ vs. 1 -L narrow-mouth bottle $=0.6$ $\mathrm{cm}^{2} / \mathrm{mL}$ ), which may explain the potential release of detectable amounts of alkalinity in our experiments (also $\mathrm{see}^{28}$ ). Huang et al. ${ }^{8}$ found soda-lime glassware increased $\mathrm{A}_{\mathrm{T}}$, but reported no effect of borosilicate glass vials on seawater stored for up to 47 days. Differences between our results and Huang et al. ${ }^{8}$ may be because we (i) tested the effects of borosilicate glass using untreated water standards as our benchmarks, (ii) used different brands/shapes of high quality borosilicate glassware that are produced by different manufacturers, which also have different surface area to volume ratios, or (iii) tested for longer storage periods. For example, we found a minor but detectable effect of borosilicate glass on the $A_{T}$ of seawater after 6 months, but not at 0 or 1 month (Fig. 1). The effects of borosilicate glass on $\mathrm{A}_{\mathrm{T}}$ may also be concealed by the effects of $\mathrm{HgCl}_{2}$. When tested in isolation, borosilicate glass and $\mathrm{HgCl}_{2}$ had substantial, but opposing, effects on $\mathrm{A}_{\mathrm{T}}$. In contrast, samples treated with $\mathrm{HgCl}_{2}$ and stored in borosilicate glass vials often had equivalent $\mathrm{A}_{\mathrm{T}}$ to benchmark controls, similar to the generally stable $\mathrm{A}_{\mathrm{T}}$ of $\mathrm{HgCl}_{2}$ poisoned seawater certified reference materials stored in borosilicate glass bottles for up to 3 years ${ }^{48}$. These findings highlight the importance of considering the potential for interactive effects when assessing the efficacy of experimental methods.

The prevention of biological activity that could alter $\mathrm{A}_{\mathrm{T}}$ is a primary aim of sample preservation methods $\mathrm{s}^{7,8}$. However, when we added glucose to samples to promote microbial activity, changes in DOC, $\mathrm{pH}$, and DO that could be indicative of biological activity did not substantially differ among treatments over time, nor directly correspond with changes in $A_{T}$ in different preservation treatments. Most changes in $A_{T}$ observed in our experiments were likely due to precipitation, adsorption, flocculation, dissolution, or other chemical reactions. One implication is that preservation and storage methods that are appropriate for stabilising alkalinity may be unsuitable when analysing $\mathrm{pH}$ or non-carbonate chemistry parameters where biological activity is a major concern (e.g. DOC, DO). Similar to earlier findings ${ }^{10,49,50}$, filtration and plastic storage vessels were not sufficient to prevent changes in DOC, $\mathrm{pH}$, and DO over time. Consequently, methods to preserve and store water samples need to be tailored to the specific parameter of interest.

Overall, our results suggest there is considerable potential for conventional preservation and storage methods to alter the $\mathrm{A}_{\mathrm{T}}$ of water samples, particularly from non-marine water sources. To avoid the detectable pitfalls of $\mathrm{HgCl}_{2}$ and borosilicate glassware, most water samples intended for $\mathrm{A}_{\mathrm{T}}$ analysis could instead be filtered to $0.45 \mu \mathrm{m}$, and then stored in polypropylene at $4{ }^{\circ} \mathrm{C}$ for at least 6 months. Avoiding $\mathrm{HgCl}_{2}$ preservation not only improves the precision and accuracy of $\mathrm{A}_{\mathrm{T}}$ analysis of diverse water types, but also brings environmental benefits, minimises risks to researchers, and ultimately reduces the cost associated with analysis.

\section{Data availability}

All data generated or analysed during this study are presented in this published article and its Supplementary Information file. Datasets are available from the corresponding author on reasonable request.

Received: 8 December 2020; Accepted: 15 April 2021

Published online: 11 May 2021

\section{References}

1. Doney, S. C., Fabry, V. J., Feely, R. A. \& Kleypas, J. A. Ocean acidification: The other $\mathrm{CO}_{2}$ problem. Annu. Rev. Mar. Sci. 1, $169-192$. https://doi.org/10.1146/annurev.marine.010908.163834 (2009).

2. Sippo, J. Z., Maher, D. T., Tait, D. R., Holloway, C. \& Santos, I. R. Are mangroves drivers or buffers of coastal acidification? Insights from alkalinity and dissolved inorganic carbon export estimates across a latitudinal transect. Glob. Biogeochem. Cycles 30, 753-766. https://doi.org/10.1002/2015GB005324 (2016).

3. Silverman, J. et al. Community calcification in Lizard Island, Great Barrier Reef: A 33 year perspective. Geochim. Cosmochim. Acta 144, 72-81. https://doi.org/10.1016/j.gca.2014.09.011 (2014).

4. Feely, R. A. et al. Impact of anthropogenic $\mathrm{CO}_{2}$ on the $\mathrm{CaCO}_{3}$ system in the oceans. Science 305, 362-366. https://doi.org/10.1126/ science.1097329 (2004).

5. Mos, B., Dworjanyn, S. A., Mamo, L. T. \& Kelaher, B. P. Building global change resilience: Concrete has the potential to ameliorate the negative effects of climate-driven ocean change on a newly-settled calcifying invertebrate. Sci. Total Environ. 646, $1349-1358$. https://doi.org/10.1016/j.scitotenv.2018.07.379 (2019).

6. Bockmon, E. E. \& Dickson, A. G. An inter-laboratory comparison assessing the quality of seawater carbon dioxide measurements. Mar. Chem. 171, 36-43. https://doi.org/10.1016/j.marchem.2015.02.002 (2015).

7. Dickson, A. G., Sabine, C. L. \& Christian, J. R. Guide to best practices for ocean $\mathrm{CO}_{2}$ measurements, 3, 191 (PICES Special Publication, 2007).

8. Huang, W.-J., Wang, Y. \& Cai, W.-J. Assessment of sample storage techniques for total alkalinity and dissolved inorganic carbon in seawater. Limnol. Oceanogr. Methods 10, 711-717. https://doi.org/10.4319/lom.2012.10.711 (2012).

9. Korfmacher, J. L. \& Musselman, R. C. Evaluation of storage and filtration protocols for alpine/subalpine lake water quality samples. Environ. Monit. Assess. 131, 107-116. https://doi.org/10.1007/s10661-006-9460-x (2007).

10. Schock, M. R. \& Schock, S. C. Effect of container type on pH and alkalinity stability. Water Res. 16, 1455-1464. https://doi.org/10. 1016/0043-1354(82)90244-5 (1982).

11. Somridhivej, B. \& Boyd, C. E. An assessment of factors affecting the reliability of total alkalinity measurements. Aquaculture 459, 99-109. https://doi.org/10.1016/j.aquaculture.2016.03.032 (2016). 
12. Cole, J. J. et al. Plumbing the global carbon cycle: Integrating inland waters into the terrestrial carbon budget. Ecosystems 10, 172-185. https://doi.org/10.1007/s10021-006-9013-8 (2007).

13. Raymond, P. A. et al. Global carbon dioxide emissions from inland waters. Nature 503, 355-359. https://doi.org/10.1038/natur e12760 (2013).

14. Wolf-Gladrow, D. A., Zeebe, R. E., Klaas, C., Körtzinger, A. \& Dickson, A. G. Total alkalinity: the explicit conservative expression and its application to biogeochemical processes. Mar. Chem. 106, 287-300. https://doi.org/10.1016/j.marchem.2007.01.006 (2007).

15. Kirkwood, D. S. Stability of solutions of nutrient salts during storage. Mar. Chem. 38, 151-164. https://doi.org/10.1016/03044203(92)90032-6 (1992).

16. Kattner, G. Storage of dissolved inorganic nutrients in seawater: poisoning with mercuric chloride. Mar. Chem. 67, 61-66. https:// doi.org/10.1016/S0304-4203(99)00049-3 (1999).

17. Chen, C. Y. et al. A critical time for mercury science to inform global policy. Environ. Sci. Tech. 52(17), 9556-9561. https://doi. org/10.1021/acs.est.8b02286 (2018).

18. Gloël, J., Robinson, C., Tilstone, G., Tarran, G. \& Kaiser, J. Could benzalkonium chloride be a suitable alternative to mercuric chloride for preservation of seawater samples?. Ocean Sci. 11, 947-952. https://doi.org/10.5194/os-11-947-2015 (2015).

19. Morel, F. M. M., Kraepiel, A. M. L. \& Amyot, M. The chemical cycle and bioaccumulation of mercury. Ann. Rev. Ecol. Syst. 29, 543-566. https://doi.org/10.1146/annurev.ecolsys.29.1.543 (1998).

20. Bockmon, E. E. \& Dickson, A. G. A seawater filtration method suitable for total dissolved inorganic carbon and $\mathrm{pH}$ analyses. Limnol. Oceanogr. Methods 12, 191-195. https://doi.org/10.4319/lom.2014.12.191 (2014).

21. Chanson, M. \& Millero, F. J. Effect of filtration on the total alkalinity of open-ocean seawater. Limnol. Oceanogr. Methods 5, 293-295. https://doi.org/10.4319/lom.2007.5.293 (2007).

22. Kim, H.-C., Lee, K. \& Choi, W. Contribution of phytoplankton and bacterial cells to the measured alkalinity of seawater. Limnol. Oceanogr. 51, 331-338. https://doi.org/10.4319/lo.2006.51.1.0331 (2006).

23. Hoppe, C. J. M., Langer, G., Rokitta, S. D., Wolf-Gladrow, D. A. \& Rost, B. Implications of observed inconsistencies in carbonate chemistry measurements for ocean acidification studies. Biogeosciences 9, 2401-2405. https://doi.org/10.5194/bg-9-2401-2012 (2012).

24. Doctor, D. H. et al. Carbon isotope fractionation of dissolved inorganic carbon (DIC) due to outgassing of carbon dioxide from a headwater stream. Hydrol. Process. 22, 2410-2423. https://doi.org/10.1002/hyp.6833 (2008).

25. Wilson, J., Munizzi, J. \& Erhardt, A. M. Preservation methods for the isotopic composition of dissolved carbon species in non-ideal conditions. Rapid. Commun. Mass Spectrom. 34, e8903. https://doi.org/10.1002/rcm.8903 (2020).

26. Aminot, A., Kerouel, R., Kirkwood, D. S., Etoubleau, J. \& Cambon, P. Potential contamination from glassware in the determination of phosphorus in natural waters. Int. J. Environ. Anal. Chem. 49(3), 125-138. https://doi.org/10.1080/03067319208027564 (1992).

27. Kirkwood, D. S., Aminot, A., Perttila, M. Report on the results of the ICES fourth intercomparison exercise for nutrients in sea water. International Council for the Exploration of the Sea 174, 85. https://doi.org/10.17895/ices.pub.5523. (1991)

28. Zhang, J.-Z., Fischer, C. J. \& Ortner, P. B. Laboratory glassware as a contaminant in silicate analysis of natural water samples. Water Res. 33(12), 2879-2883. https://doi.org/10.1016/S0043-1354(98)00508-9 (1999).

29. Jollivet, P. et al. Effect of clayey groundwater on the dissolution rate of the simulated nuclear waste glass SON68. J. Nucl. Mater. 420, 508-518. https://doi.org/10.1016/j.jnucmat.2011.10.026 (2012).

30. Rolland, S. et al. Effect of groundwater on the dissolution rate of the simulated nuclear waste glass SON68 under Gamma irradiation. Procedia Chem. 7, 587-592. https://doi.org/10.1016/j.proche.2012.10.089 (2012).

31. Taniguchi, M. et al. Submarine groundwater discharge: Updates on its measurement techniques, geophysical drivers, magnitudes, and effects. Front. Environ. Sci. 7(141), 1. https://doi.org/10.3389/fenvs.2019.00141 (2019).

32. Redfield, A. C., Ketchum, B. H. \& Richards, F. A. The influence of organisms on the composition of sea-water in The Sea (ed. Hill, M.N.) 26-77 (Wiley Interscience, 1963).

33. Webb, J. R. et al. Groundwater as a source of dissolved organic matter to coastal waters: Insights from radon and CDOM observations in 12 shallow coastal systems. Limnol. Oceanogr. 64, 182-196. https://doi.org/10.1002/lno.11028 (2019).

34. Dickson, A. G. Standards for ocean measurements. Oceanography 23, 34-47. https://doi.org/10.5670/oceanog.2010.22 (2010).

35. Rounds, S. A. Alkalinity and acid neutralizing capacity. US Geological Survey TWRI Book, No. 9, Chapter 6.6. (2012).

36. Bargrizan, S., Smernik, R. J. \& Mosley, L. M. Constraining the carbonate system in soils via testing the internal consistency of $\mathrm{pH}$, $\mathrm{pCO}_{2}$ and alkalinity measurements. Geochem. Trans. 21, 1-10. https://doi.org/10.1186/s12932-020-00069-5 (2020).

37. Chen, Y., Zhang, L., Xu, C. \& Vaidyanathan, S. Dissolved inorganic carbon speciation in aquatic environments and its application to monitor algal carbon uptake. Sci. Total Environ. 541, 1282-1295. https://doi.org/10.1016/j.scitotenv.2015.10.025 (2016).

38. Song, S. et al. An important biogeochemical link between organic and inorganic carbon cycling: Effects of organic alkalinity on carbonate chemistry in coastal waters influenced by intertidal salt marshes. Geochim. Cosmochim. Acta 275, 123-139. https://doi. org/10.1016/j.gca.2020.02.013 (2020).

39. Barron, J. L., Dyrssen, D., Jones, E. P. \& Wedborg, M. A comparison of computer methods for seawater alkalinity titrations. . Deep Sea Res Part A. Oceanogr. Res. Pap. 30, 441-448. https://doi.org/10.1016/0198-0149(83)90077-8 (1983).

40. Sharp, J. D. \& Byrne, R. H. Interpreting measurements of total alkalinity in marine and estuarine waters in the presence of protonbinding organic matter. Deep Sea Res. Part I: Oceanogr. Res. Pap. 165, 103338. https://doi.org/10.1016/j.dsr.2020.103338 (2020).

41. Kim, H.-C. \& Lee, K. Significant contribution of dissolved organic matter to seawater alkalinity. Geophys. Res. Lett. 36, L20603. https://doi.org/10.1029/2009GL040271 (2009).

42. Ko, Y. H., Lee, K., Eom, K. H. \& Han, I.-S. Organic alkalinity produced by phytoplankton and its effect on the computation of ocean carbon parameters. Limnol. Oceanogr. 61, 1462-1471. https://doi.org/10.1002/lno.10309 (2016).

43. Koeve, W. \& Oschlies, A. Potential impact of DOM accumulation on $f \mathrm{CO}_{2}$ and carbonate ion computations in ocean acidification experiments. Biogeosciences 9, 3787-3798. https://doi.org/10.5194/bg-9-3787-2012 (2012).

44. Ravichandran, M. Interactions between mercury and dissolved organic matter--a review. Chemosphere 55, 319-331. https://doi. org/10.1016/j.chemosphere.2003.11.011 (2004).

45. Whalin, L., Kim, E.-H. \& Mason, R. Factors influencing the oxidation, reduction, methylation and demethylation of mercury species in coastal waters. Mar. Chem. 107, 278-294. https://doi.org/10.1016/j.marchem.2007.04.002 (2007).

46. Hahne, H. C. H. \& Kroontje, W. Significance of $\mathrm{pH}$ and chloride concentration on behavior of heavy metal pollutants: Mercury(II), Cadmium(II), Zinc(II), and Lead(II)1. J. Environ. Qual. 2, 444-450. https://doi.org/10.2134/jeq1973.00472425000200040007x (1973).

47. Bunker, B. C. Molecular mechanisms for corrosion of silica and silicate glasses. J. Non-Cryst. Solids 179, 300-308. https://doi.org/ 10.1016/0022-3093(94)90708-0 (1994).

48. Dickson, A. G., Afghan, J. D. \& Anderson, G. C. Reference materials for oceanic $\mathrm{CO}_{2}$ analysis: a method for the certification of total alkalinity. Mar. Chem. 80, 185-197. https://doi.org/10.1016/S0304-4203(02)00133-0 (2003).

49. Kampbell, D. H., Wilson, J. T. \& Vandegrift, S. A. Dissolved oxygen and methane in water by a GC headspace equilibration technique. Int. J. Environ. Anal. Chem. 36(4), 249-257. https://doi.org/10.1080/03067318908026878 (1989).

50. Tupas, L. M., Popp, B. N. \& Karl, D. M. Dissolved organic carbon in oligotrophic waters: experiments on sample preservation, storage and analysis. Mar. Chem. 45, 207-216. https://doi.org/10.1016/0304-4203(94)90004-3 (1994). 


\section{Acknowledgements}

This study was supported by funding from the Australian Research Council to BM and SD (IN200100026), IS (FT170100327), and IS, BK, and SD (LE170100007), and AgriFutures Australia to SD and BM (PRJ-010284). The authors thank two anonymous reviewers for their helpful comments. We also thank Professor Andrew Dickson for helpful discussions regarding a previous version of the manuscript.

\section{Author contributions}

All authors contributed to conceptualisation and data interpretation, and approved the article for submission. $\mathrm{CH}$ and BM collected samples. BM and $\mathrm{CH}$ conducted the experiments and ran chemical analyses. BM did statistical analyses, with input from BK. BM and $\mathrm{CH}$ wrote the manuscript. SD, IS, and BK provided critical feedback.

\section{Competing interests}

The authors declare no competing interests.

\section{Additional information}

Supplementary Information The online version contains supplementary material available at https://doi.org/ 10.1038/s41598-021-89110-w.

Correspondence and requests for materials should be addressed to B.M.

Reprints and permissions information is available at www.nature.com/reprints.

Publisher's note Springer Nature remains neutral with regard to jurisdictional claims in published maps and institutional affiliations.

(c) (i) Open Access This article is licensed under a Creative Commons Attribution 4.0 International License, which permits use, sharing, adaptation, distribution and reproduction in any medium or format, as long as you give appropriate credit to the original author(s) and the source, provide a link to the Creative Commons licence, and indicate if changes were made. The images or other third party material in this article are included in the article's Creative Commons licence, unless indicated otherwise in a credit line to the material. If material is not included in the article's Creative Commons licence and your intended use is not permitted by statutory regulation or exceeds the permitted use, you will need to obtain permission directly from the copyright holder. To view a copy of this licence, visit http://creativecommons.org/licenses/by/4.0/.

(C) The Author(s) 2021 